\title{
BASAL FREEZING OF SQUEEZED WATER: ITS INFLUENCE ON GLACIER EROSION
}

\author{
by \\ R. A. Souchez and J.-L. Tison \\ (Laboratoire de Géomorphologie, Faculté des Sciences, Université Libre de Bruxelles, \\ Avenue F. D. Roosevelt 50, B-1050 Bruxelles, Belgium)
}

\begin{abstract}
The basal ice layer of Glacier de Tsidjiore Nouve in the Swiss Alps consists of debris bands and associated clear ice lenses. This layer is due to refreezing of squeezed water at the sole of the glacier, as evidenced by the chemical properties of the ice. Active erosion processes include entrainment of debris in the basal ice layer and abrasion on rock protuberances immediately down-glacier. The formation of the basal ice layer requires that the temperature of the squeezed water, which is determined by the pressure-melting point within the basal ice, should be below the freezing temperature of the pore water in the subglacial debris layer. This would be the case if the pore water were at a pressure lower than the basal ice pressure.
\end{abstract}

\section{INTRODUCTION}

Studies of glacier soles in the Alps have shown the existence in certain circumstances of a basal ice layer many millimetres thick. This differs from the glacier ice above it by its structural and textural properties and by its unusual chemistry (Vivian 1975, Souchez and Lorrain 1978). One general characteristic is a substantially higher debris content than in the bulk of the glacier.

The basal ice layer can be formed by freezing of water at the ice-bedrock interface. Incorporated debris is carried away down-glacier by $i$ ts displacement. On the other hand, glacier abrasion is dependent on the presence and concentration of debris at the sole of the glacier (Röthlisberger 1968, Sugden and John 1976). Present-day glacier erosion is thus likely to occur at, and down-glacier from, a site where a basal ice layer can be formed. It is thus critical for the study of present-day glacier erosion in the Alps to understand the formation of a basal ice layer. A better insight into this problem can be gained by studying the chemical properties of the basal ice layer because they can give us some indication on the origin of melt water that refreezes at the base.

\section{DESCRIPTION OF THE GLACIER SOLE}

Studies on Glacier de Tsidjiore Nouve in the western Swiss Alps (Souchez and Lorrain 1978, fig. 1) were continued in crevasses and in a tunnel (Fig. 1). Along the margin, near the surface, a first sequence of basal layers can be easily studied in crevasses caused by a bend of the glacier below the ice-fall. Most of this se- quence consists of white or grey bubbly ice forming wedges or layers up to $500 \mathrm{~mm}$ thick. The difference in colour between white and grey ice is due to the density and distribution of gas bubbles. In white ice, the bubbles are spherical, with a diameter of 1 or $2 \mathrm{~mm}$ and are dispersed within the ice in a dense pattern. If, on the other hand, the bubbles are larger (about $4 \mathrm{~mm}$ ), are less frequent, and are elongated in the plane of the foliation, the ice appears grey. Clear, bubble-free ice occurs as thin layers distributed within the bubbly ice or as layers a few $\mathrm{cm}$ thick associated with pockets or lenses of debris-rich ice. This clear ice is later described as "basal bubble-poor ice at the margin". Foliation is generally subvertical near the margin but some layers are folded.

In the same area, a slight separation between the glacier sole and the bedrock at the base of a crevasse gives way to a natural subglacial tunnel extending for $20 \mathrm{~m}$ towards the centre of the glacier. Near the entrance of the tunnel $2 \mathrm{~m}$ of bubbly ice are interspersed with clear ice in equal proportions. The clear ice consists of layers up to $10 \mathrm{~mm}$ thick separated by debris bands of approximately the same thickness with occasionally rock fragments. A layer of bubbly ice approximately $100 \mathrm{~mm}$ in thickness separates two sets of clear and debris-rich ice. Further along the tunnel, this bubbly ice disappears and the sequence of basal ice layer is reduced to lenses of clear ice about $10 \mathrm{~mm}$ in thickness above a debris band twice as thick (Fig. 1).

\section{FORMATION OF THE BASAL ICE LAYER}

Since our recent papers (Souchez and Lorrain 1.978, Souchez and others 1978). further chemical tests were conducted on different types of ice encountered in and near the tunnel, including snow and ice on stagnant water in crevasses partially filled with morainic debris. Methods of sampling and analys is were the same; many precautions were taken to reduce the contribution from contamination to the background noise level of the atomic absorption spectrophotometer and to control chemical changes caused by the melting of the samples. Figure 2 shows the alkali versus the alkaline-earth content of the samples. Each point on the diagram represents one sample.

Snow, some samples of glacier ice, and most samples of basal bubble-poor ice at the margin are located in the lower left part of Figure 2. They represent, from a chemical point of view, a single population. Two trends can be observed. 


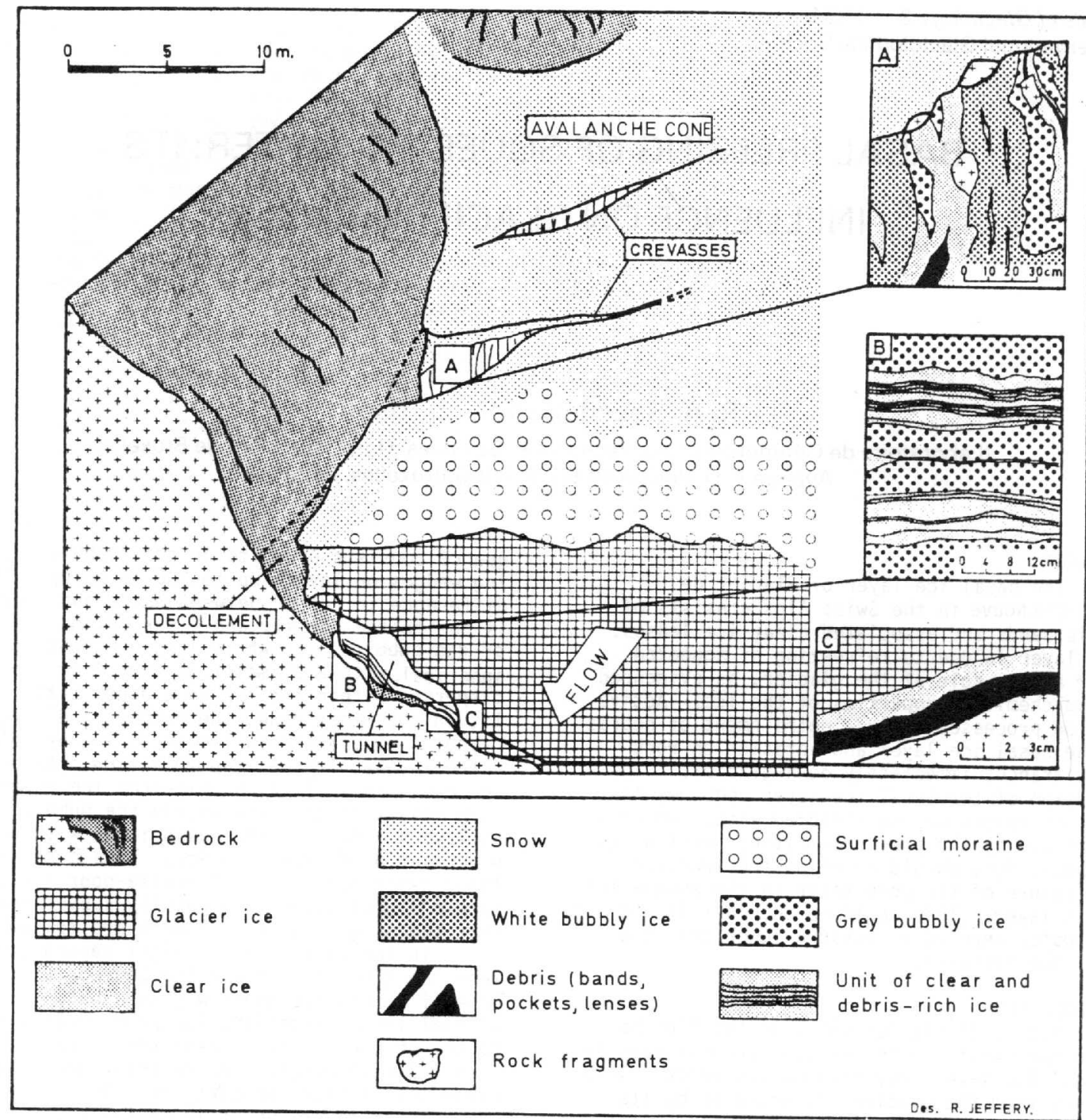

Fig.1. Detailed map and vertical cross-sections near the eastern margin of Glacier de Tsidjiore Nouve.

If, during ice formation, prolonged contact with rock particles occurs, the $\mathrm{Na}+\mathrm{K} / \mathrm{Ca}+\mathrm{Mg}$ ratio will be greatly reduced because of a preferential contribution in alkaline-earths by the particles. This can be shown by the very low $\mathrm{Na}+\mathrm{K} / \mathrm{Ca} \mathrm{Mg}$ ratio in subglacial flow $(0.05-0.09)$, in supraglacial streams $(0.11-0.14)$, and by the following experiment. If we leave the fine particles $(<50 \mu \mathrm{m})$ of morainic deposits from the Tsidjiore Nouve glacier in contact with melted ice from the same glacier at $0^{\circ} \mathrm{C}$ and for various periods ( 1 to $320 \mathrm{~min})$, the $\mathrm{Na}+\mathrm{K} / \mathrm{Ca}+\mathrm{Mg}$ ratio decreases systematically in the course of time, a value of 0.18 being recorded after 1 min of contact and a value of 0.05 after 320 min (Souchez and others 1978). Some glacier-ice and pond-ice samples fall in this category. The trend is indicated by the lower arrow.

If, on the other hand, selective flushingout of ions occurs as a consequence of water squeezing, ice due to refreezing of this water will have a much higher $/ \mathrm{Na}+\mathrm{K} / \mathrm{Ca} \mathrm{Mg}$ ratio. This has been suggested by us previously for the Tsidjiore Nouve glacier (Souchez and others 1978). The trend is given by the upper arrow in Figure 2. Basal bubble-poor ice in the tunnel falls into this category, showing $\mathrm{Na}+\mathrm{K} / \mathrm{Ca}+\mathrm{Mg}$ ratios varying from 0.34 to 0.85 with a mean value of 0.58 . A fractional melting experiment shows results along the same lines. In a suitable hot-water bath, sections from Tsidjiare Nouve glacier-ice cores are locally heated at the base. As soon as it is produced, $10 \mathrm{ml}$ of melt water is recovered with the aid of a polyethylene syringe and immediately press-filtered. (The procedure is similar to that described in Souchez and others (1973) for Glacier d'Argentière.) Successive $10 \mathrm{ml}$ samples of filtered water are taken and analysed. Figure 3 shows a sharp decrease in $\mathrm{Na}+\mathrm{K} / \mathrm{Ca}+\mathrm{Mg}$ during melting. This indicates a selective migration of ions, alkalis being more easily flushed out than a kaline-earths. Moreover a systematic decrease in cationic content takes place from the first to the last filtered sample. This is connected with a dilution of the interstitial water which is mainly located at three- and four-grain intersections.

Robin (1976) suggests that pressuremelting within the basal ice mass, as distinct from processes at the ice-bedrock interface, may be responsible for the formation of excess water in zones of high-pressure ice upstream of glacier-bed obstacles and that this water is 


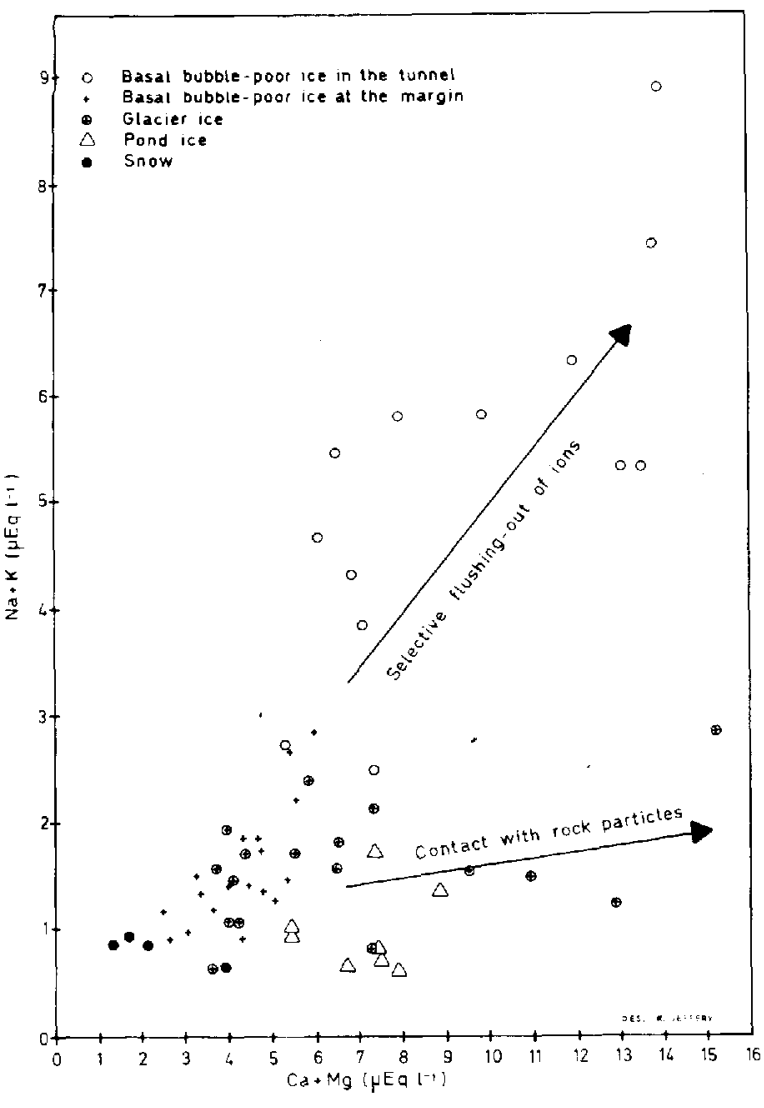

Fig.2. Relationship between alkali and alkaline-earth content of the types of ice studied. squeezed out of the ice by the pressure. Goodman and others (1979) have published another paper which justifies some of the speculations made. It is difficult to say that our chemical studies demonstrate the occurrence of the Robin effect, although we think the squeezed water must have a local origin in the basal part of the glacier. Indeed, there is no significant difference in major cations between surface glacier ice and basal glacier ice along the vertical, above the basal ice layer. If selective entrainment of ions by overall percolation is the dominant feature, a gradient would be expected in glacier ice. However, further studies are clearly needed in that direction. The chemical composition of basal bubblepoor ice in the tunnel implies a limited contact with rock particles. Since this kind of ice only exists as lenses above a debris band in the basal ice layer visible in the tunnel, it may be supposed that at first squeezed water invades the pores of a subglacial permeable sediment and refreezes. Then this frozen layer acts as a barrier allowing the formation of lenses of debris-free bubble-poor ice above, in the lee of small stones projecting upwards from the frozen sediment layer. Ion exchange between water and particles is thus greatly reduced. Moreover the relatively high ionic strength of squeezed water diminishes the rate of this ion exchange.

For water to freeze in the uppermost layer of the subglacial sediment, the ice pressure must exceed the water pressure within the morainic deposit below. Because the temperature of the squeezed water is determined by the pressure-melting point within the basal ice, it can be below the freezing temperature of the interstitial water if this water is at a lower pressure. A certain permeability of the frozen sediment layer must exist. Just enough leakage is probably sustained to lead to a pressure drop across the frozen layer in accordance with the temperature profile.

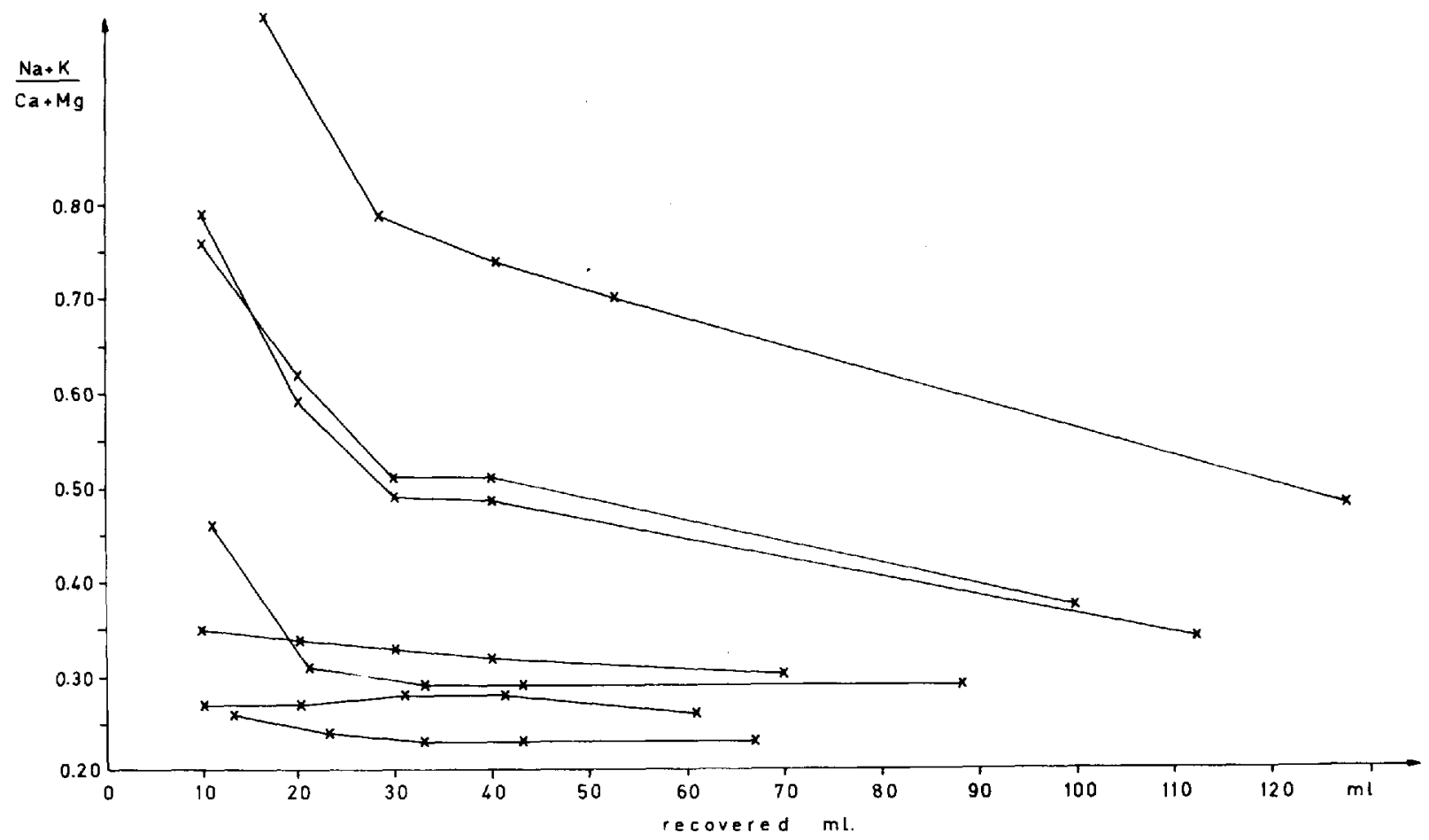

Fig.3. The alkali-alkaline-earth ratios for seven glacier ice samples subjected to fractional melting. 
PRESENT-DAY GLACIER EROSION

The debris band and associated clear ice lenses visible in the tunnel are displaced with the glacier. Near the end of the tunnel this ice-rich sediment makes contact with a rock protuberance on the side wall. The polished bedrock is partly covered with fine silt resulting from crushing. Striae are impressed in the silt and in the rock. One of them can be traced towards the tool, a rock fragment still present in the frozen sediment at the glacier sole. This reflects present-day grinding and active sliding. The debris-rich ice at the base acts much as sand paper. A situation in which bed protuberances exist immediately down-

glacier of a site where a debris-rich basal ice layer is formed seems favourable for attrition grinding in the area investigated.

\section{CONCLUSION}

Effective present-day erosion at the base of the Glacier de Tsidjiore Nouve occurs both by entrainment of debris where the sole of the glacier consists of a debris band and associated clear ice lenses and by abrasion on rock protuberances down-glacier from a site of formation of a basal ice layer. This basal erosion is dependent on refreezing of squeezed water at the interface.

The considerations developed in this paper point to the need for further study of the sites of occurrence of the water squeezing-refreezing process since glacier erosion is related to it.

\section{ACKNOWLEDGEMENTS}

Easy access to Glacier de Tsidjiore Nouve was provided by Grande Dixence SA. Thanks for this are due to Ing Bezinge and Ing Arlettaz. One of the authors ( $J-L T)$ is indebted to the Belgian Science Foundation for his present status.

\section{REFERENCES}

Goodman D J, King G C P, Millar D H M, Robin $G$ de $Q 1979$ Pressure melting effects in basal ice of temperate glaciers: laboratory studies and field observations under Glacier d'Argentière. Joumal of Glaciology 23(89) : 259-271

Robin $G$ de 01976 Is the basal ice of a temperate glacier at the pressure melting point? Joumal of Glaciology 16(74): 183-196

Röthlisberger H 1968 Erosive processes which are likely to accentuate or reduce the bottom relief of valley glaciers. International Association of Scientific Hydrology Publication 79 (General Assembly of Berm 1967 - Snow and Ice): 87-97

Souchez R A, Lorrain R D 1978 Origin of the basal ice layer from Alpine glaciers indicated by its chemistry. Jourmal of Glaciology 20(83): 319-328

Souchez R A, Lorrain R D, Lemmens MM 1973 Refreezing of interstitial water in a subglacial cavity of an Alpine glacier as indicated by the chemical composition of ice. Journal of Glaciology 12(66): 453459

Souchez R A, Lemmens $M M$, Lorrain R D, Tison J-L 1978 Pressure-melting within a glacier indicated by the chemistry of re-gelation ice. Nature 273(5662): 454-456

Sugden DE, John B S 1976 Glaciers and Landscopes. London, Edward Arnold

Vivian R 1975 Les glaciers des Alpes occidentales. Grenoble, Imprimerie Aliier 